\title{
Boekhandel Tan Khoen Swie, press movement, and Javanese public sphere in the colonial age 1915-1950
}

\section{Boekhandel Tan Khoen Swie, pergerakan pers, dan ruang publik orang Jawa masa kolonial 1915-1950}

\section{$\underline{\text { Ratya Anindita }}^{1)}$, I Wayan Suyadnya ${ }^{2)}$, Ary Budiyanto ${ }^{3)}$, \& Megasari Noer Fatanti ${ }^{4)}$}

\author{
1) Faculty of Humanities, Universitas Brawijaya \\ 2) Department of Sociology, Universitas Brawijaya \\ 3) Department of Anthropology, Universitas Brawijaya \\ 4) Department of Communication, Universitas Brawijaya \\ E-mail: ratyaa@ub.ac.id,iway.s@ub.ac.id, \\ yrelief@yahoo.com,megafatanti@staff.ub.ac.id \\ Jalan Veteran Malang 65145. Telepon: 0341-57587
}

\begin{abstract}
The research attenots to analysis the historical genealogy and press movement and Javanese public sphere in the colonial age, 1915-1950. By focusing the site of Boekhandel Tan Khoen Swie (TKS) in Kediri - East Java during the colonial period, this research is specifically to explore the roles of TKS and Tan Khoen Swie's ideas (as a person) in the press movement in East Java over 35 years. The research used qualitative research with historical-discourse perspectives. It combines the archeology/genealogy methods proposed by Michel Foucault, historical and archives study. Through a historical archive investigation, both of material and ego documents, the study mapped on how the production of the public sphere in colonial age happened. The result of this study shows that the works and ideas published by through Boekhandel Tan Khoen Swie (TKS) are full meaning of spiritual and culture values. TKS has encouraged the transformation of Javanese values to the wider community. We argue that the idea and efforts of the public sphere in Javanese community during the colonial era, especially through it controversial publications. As an individual, Tan Khoen Swie established himself as the cosmopolitan elite in the fight against the colonialism. In other words, the study is success to showed the importance roles of Tan Khoen Swie inspiring the emergence of press movement in East Java and it also supports for creating the alternative public sphere for Javanese.
\end{abstract}

Keywords: social-history of press, Tan Khoen Swie, post-colonial, public sphere

\begin{abstract}
Abstrak
Penelitian ini secara umum bertujuan untuk memetakan studi genealogi sejarah dan pergerakan pers dalam membentuk ruang publik orang Jawa di masa kolonial 1915-1950. Dengan mengambil situs pada usaha penerbitan Boekhandel Tan Khoen Swie di Kediri Jawa Timur pada periode tersebut, secara spesifik penelitian ini mengeksplorasi peran Boekhandel Tan Khoen Swie dan gagasan Tan Khoen Swie (sebagai individu) dalam pergerakan pers di Jawa Timur masa kolonial kurun waktu 35 tahun. Melalui penelusuran arsip sejarah baik dokumen tertulis maupun secara lisan, penelitian ini berupaya menguraikan nilai-nilai lokal yang membentuk ruang publik pada masa kolonial yang luput dari kajian komunikasi, sosiologi maupun sejarah pada masa itu. Penelitian ini menggunakan metode kualitatif dengan pendekatan historical-discourse yaitu menggabungkan metode genealogi/arkeologi Foucault, pendekatan historis dan studi arsip. Hasil penelitian menunjukkan bahwa karya dan gagasan yang diterbitkan melalui usaha penerbitan Tan Khoen Swie sarat akan nilai-nilai spiritual. Usaha penerbitan Tan Khoen Swie telah mendorong transformasi nilai-nilai kesusastraan Jawa kepada masyarakat luas. Penelitian ini juga memperlihatkan bahwa gagasan dan usaha penerbitan TKS berperan membentuk ruang dikursus pada orang Jawa khususnya melalui karya kontroversial. Sebagai individu, Tan Khoen Swie membuktikan dirinya sebagai salah satu elite kosmopolit dalam melakukan perlawanan terhadap penjajah kolonial. Dengan kata lain, hasil penelitian ini berhasil menunjukkan pentingnya peran Tan Khoen Swie menginspirasi kemunculan pers di Jawa Timur dan sekaligus memunculkan ruang publik alternatif bagi orang Jawa.
\end{abstract}

Kata kunci: sejarah pers, ruang publik, Tan Khoen Swie, post-kolonial 


\section{Introduction}

“..., the significant questions in the study of media remain questions about conciousness and society. I most concerned with the media tell us about differences between our own times and those of previous areas" (Tuchman 1983:331).

This research took a focus on genealogy studies of the history of the press (mass media) during the colonial period 1915-1950 and is the study of the discourse of public space in colonial Java society. Specifically this research is an exploration of the role of Tan Khoen Swie publishing business and its influence on the press movement in the Dutch East Indies in the formation of public spaces in that period. The development of the press during the press movement was one of the central themes in the study of the late Dutch colonialism in Indonesia. There have been many studies showing how in the time of the movement, the contribution of the press can not be separated from the national awakening of Indonesia (Kartodirjo 1992, Adam 2003). The movement of the press was the occurrence of an awareness of nationalism in the colonial period. The press at that time was instrumental in fostering the emergence of nationalism awareness through continuous construction so that the people feel in one community. Anderson called the community the "pictured community" concept, a community that emerged during the colonial period because of the role of print capitalism in the Indies (Anderson 2001, Anderson 2006, Dhakidae 2001). The role of the rich cosmopolitan elite, to print books, magazines, and newspapers in folklore, makes the circulation of publications massive. Dutch-language, Malay, Chinese and local languages (Javanese, Sundanese and Minang) political leaflets were also produced in the colonial era with the aim of mobilizing nationalism in the Dutch East Indies. Thus, It can not be denied that the movement of the press ultimately not only talks about the birth of the nationalism discourse but also opens the contributions of individuals and groups of cosmopolitan elites in the form of public spaces. The formation of public spaces in these early days is often overlooked in the study of Indonesian press history.

The loss of discourse of the formation of public space in the early days of colonialism occurred due to the strengthening of the focus of study on the role of the press in the formation of nationalism within the scope of macro political phenomena and public space issues is a relatively new theme in the study of the history of the press. In the context of macro-political phenomena, the fundamental change of social structure from feudal to modern in Javanese society is the main focus of the study of press movements towards the end of the nineteenth century up to the beginning of the 20th century (Riyanto 2000). Some of the factors claimed to be the cause of the transformation were the weakening of the power of the Javanese Islamic empires at the time and the emergence of bureaucratic Dutch colonial authority (Ricklefs 2007). Other factors are (1) the penetration of capitalistic system in indigenous economic system based on agriculture which resulted in the emergence of stratification system / segmentation of social classes in Java (Kartodirjo 1992), (2) the emergence of a system of forced cultivation (Cultuurstelsel) applied by the colonial government under Governor Johannes van der Bosch (1780-1844) (Ricklefs 2007:252-253), and (3) the increase of the amount of the population, and the emergence of the movement of Islamic groups and the learned classes of the priyayi class. While the study of the public space on the Javanese is not focused on the Javanese culture itself. Subijanto (2014), for example shows that the history of openbare vergaderingen (general meeting) was an important part of the anti-colonial popular movement in the Indies in 1920-1926, this is one of the alternative forms of public space. But the argument of this research finds evidence that far before, the conception of public space has also emerged in the culture of the Javanese through other forms and one of them is discussed by the results of this study.

The concept of public space in the theoretical theories of social sciences was introduced by Habermas (1990), the German philosopher and sociologist, through his book Strukturwandel der Öffentlichkeit. Untersuchungen zu einer Kategorie der bürgerlichen Gesellschaft published in 1962 [1990]. This concept is taken from the history of the bourgeois public space of Germany in the 18th century. The concept of public space stands alone and has the independent character of state and market power (Subijanto 2014). Public sphere (Öffentlichkeit) is a social life space where individuals can come together to discuss freely and identify social problems and through this discussions implied 
the implications on political action. Thus the public space has huge consequences for driving behavior that exists in the sphere of the state and market (Habermas 1990). It means that public space allows individuals through their communicative action to achieve its goals cooperatively through understanding the situation altogether. This will be achieved if the public space guarantees the use of rationality and openness to logic and opinions. It is clearly stated in Habermas's idea that the essence of social change ensures that the "lebenwelt" or public space is autonomous or in other words free from the power of "system" (systemwelt).

There have been many criticisms of public space theory proposed by Habermas, especially about the idealization of the German bourgeois public space concept with another public space concept which might have already existed in different definitions. Other critics have also been addressed about the position of the public space of the nineteenth century, in colonial times, striking almost everywhere in the world (Kaviraj 1997, Subijanto 2017). Theoretically, an article from Eley (1996) on the formation of public space among the plebeian public provides a profound insight into this research. Eley invites us to see the possibility of the formation of public space as a mechanism or impulse that is very particularistic in the nineteenth century. One of the important things of Eley's idea is that the possibility of public space is present through repression of the regime as in the colonial era. The idea raises the belief that public space grows in different ways, not only in the context of the liberal society of capitalism. The idea raises the belief that public space grows in different ways, not only in the context of the society of liberal capitalism. Through a genealogical trace toward this kind of past knowledge artifacts, the possibility to dismantle the public spaces of the colonial era and the post era is very open.

Dialogic society is one of the characteristics in the public sphere, because its existence encourages the formation of rationality in modern society (Smith 1992, Baker 1996, Calhoun 1996). Freedom of speech tradition in European societies has created a great crisis of knowledge in the history of human civilization and this gave birth to a social movement to emerge a new age called the Enlightenment. The knowledge crisis is driving the increasing awareness of European society for their social life. While it can be acknowledged that social communication is not relatively a new thing in human history, yet these impulses culminate when the process creates an age in which rationality serves as a new foundation for human life. The widespread of nationalism and the formation of the nation-state concept can not be separated through such dialogical processes and discourses. In the language of Ben Anderson (2006) the concept of a European nation-state was first formed in this way through what he called the "national print-languages." Thus, the publishing business has an important function in creating discourse on nationalism and this has implications for the birth of public space in European society. Its existence was then extended to the colonies of European society, one of which is the Dutch East Indies (Indonesia).

The study of the press history by putting a focus on specific publishing efforts has not been much done and if there were some view of the role in its efforts to help Indies independence from colonial practice. Many use Malay as their introduction in addition to Dutch (Adam 2003, Subijanto 2017). Through the searches of periodical publications in that newspapers, these traces of Dutch East Indies nationalism can be traced. However, not all Dutch Indies publishing business attempts to used Malay in that time since their orientation was not nationalism but rather an attempt to preserve culture, especially Javanese culture. Some of the newspapers such as Bromartani and Panjebar Semangat represent the newspaper business and Boekhandel Tan Khoen Swie (TKS, to refer to his business) representing the publisher. There were numerous efforts has been done in explaining the press history through the newspaper publishing business previously. While the book publishing business has almost never been done and this research is on the design of this study. The TKS publisher, as a publisher devoting attention to the strengthening of Javanese culture, has published numerous printed works in the form of controversial books that generate public debate. Indirectly the emergence of controversial books, such as Primbon Djabaja, Serat Siti Jenar, Babad Kediri, Gatolotjo, Dharmogandul and Asmorobangun, have led to long discussions and debates for the people of Java at the time. Because of this long debate, in some cities such as Kediri, Malang, Blitar, Surabaya, Madiun to Surakarta 
sprang up the discussion groups. Because the books published by TKS are considered to often provide different information, it is triggered a new habit in Javanese society to sit together and give each other certain views. Indeed in the course of these discussions not only occur in official cultural forums, but also occurs in other spaces such as small stalls on the roadside. Those monthly community is still standing and is still actively conducting routine discussion activities in several cities in East Java such as Kediri and Blitar up untill now. When referring to these periods, it can be seen that the symptoms of the formation of the concept of "public space" existed at that time. Perhaps it could be that the earlier periods when the kingdoms of Airlangga, Kediri, Majapahit and other kingdoms which introduced the written language in the form of text in the form of the book had spawned "limited public space" among the nobles and scholar.

The image that comes to mind as researchers is then how is the form of public space when it was then? Does it look like cafes in France or beautiful gardens in Germany? Or is it just a coffee shop by the side of the road, a market, a field and a street? The questions are finally pursed as a question that was initiated in this research is how the Boekhandel TKS contributions and TKS ideas (as individuals) in the creation of press movement and public space of the Javanese in East Java in colonial period 19151950 ? Of course, the researcher argues that public spaces obviously mean beyond their physical capacity. This space is active and the meanings formed freely by any party and also depend on social awareness at that time. The existence of Javanese public spaces in particular becomes attractive because of its existence along with awareness of knowledge in Javanese culture at that time.

This study strongly believes that the study of the relationship of consciousness and society in the present and the past is the essence of media studies (Tuchman 1983). Nevertheless, the researcher does not intend to reveal the historical truth about the role of TKS in the colonial press movement, but as it is claimed by Foucault (1972) that this study will be relevant to see the truth as a beginning of the discourse itself (oritatif and legetimate). Thus, the researcher placed the position of Boekhandel Tan Khoen Swie as the root or the beginning of the genealogical consciousness of public space and the spirit of anti-colonialism amidst the dominance of other press history discourses in East Java and Indonesia. In this research, TKS is considered as the beginning of the formation of public space discourse, historical pluralism and separated from the dominant of dominant discourse on the formation of public space of Javanese society. Therefore, the events that occurred during the period of Tan Khoen Swie's publishing business activity were viewed as an entity of an independent historical truth unrelated to any event. Referring to the exposure of this study, it is laid out in the framework of how the early beginnings of discourse about the involvement of ideas / TKS ideas in the press and public space of the Javanese. So we set up a genealogical study to explore Tan Khoen Swie's ideas in a complex rational fabric of interest and sensitivity in Javanese society in the history of the press and the formation of public space.

\section{Research Methods}

This research used a qualitative approach with Foucault's method of archeology-genealogy of knowledge. Foucault's notion of socio-historical issues is of interest to the history and development of Boekhandel Tan Khoen Swie's publishing business and its influence on the press movement in colonial era in East Java. It should be noted that the archeology-genealogy fouched by Foucault is considered a revolutionary method of research. The Archaeological Method of Science, Foucault is interested in investigating the historical phenomenon. Through his archaeological method, Foucault sought to trace the historical elements by investigating 'discursive formations', 'statements in question' and 'written' in a historical context. Archeology is a metaphorical concept to refer to something called the archive, which aims to see discourse in society. In other words, archeology serves only to analyze concept formation without correlating it with the idealistic horizon and empirical progress of a thought. It is important to emphasize that in this archaeological method is far from archaeological discipline, that is the study of the past. As Foucault (1972:135) points out, its archaeological "... it does not relate analysis to geological excavation". While genealogy method is 
a method that uses discourse or discourse analysis which consist of a set of statement that turn into social reality. Genealogy finds out how power behind the social reality and has its own way of being understood from the archives (Scheurich \& McKenzie 2011). As Kali writes in his book Discourse of Sexuality that genealogy does not intend to seek the origin of such archeology, but trying to dismantle and question the epistemes-social practice and human self (2013:39).

The strength of this research lies in the collection of data through archives / historical documents that tell about Tan Khoen Swie and the presence of business of Boekhandel Tan Khoen Swie publication during the period 1915-1950 and interviews with informants who know the existence of TKS. Researchers explore every remaining historical artifacts, such as the collection of TKS published books owned by the family as well as the exploration of previous research results related to the TKS in local and university libraries. The purpose of the researcher is to search history archive not only to see the connectedness of archive which is guarded by certain 'regime of power / knowledge' (civilization), but to see the principle / rule that makes a discourse appear and disappear. The discourse referred to in this research is how the works of TKS encouraged the creation of public space in Java society in 1915-1950. Through the genealogical approach, researchers try to find out how the 'power' represented in the works of TKS can flow in the discussions of Java society in the colonial period. Such power is reflected in the distribution of works of TKS to the wider public. According to Foucault (1972) discourse exercises power with four principles: (1) power is a relation; (2) power is widespread; (3) power is productive; (4) power works through normalization and regulation. While 'power' is among the discourses in society.

According to us, the application of the power referred to by Foucault in relation to this research is how the works of the publications of TKS are able to encourage the creation of discourse in society about the knowledge of Javanese values. The intensity of TKS publishes works full of Javanese values shows a different position with other publishers emerging in the same era. Determination of research location based on the reason for the existence of publisher of TKS which is located in Kediri City, precisely in Jalan Dhoho (Toko Surabaya) and availability of book published by TKS. Documentation techniques are also used in this research by documenting photos of Tan Khoen Swie that are kept by the family, the works of TKS which are still preserved until now. The photographs collected by the researchers are a source of data to see how the personal life of Tan Khoen Swie when he wa still alive. It can be concluded that the technique of collecting research data using four techniques are: First, the observation which has been done on: (i) collection of works of Boekhandel Tan Khoen Swie (TKS) since 1917-1960; (ii) The social environment in which Boekhandel Tan Khoen Swie (TKS) is built, which includes observation of the social environment where TKS publisher is located, the social condition around TKS publisher back then and present, the responses of local residents about the existence of TKS publisher, the response of local governments to the existence of TKS as a very active publisher in the colonial period, as well as the sustainability of local values raised by TKS in each of his work. Other observations were also conducted on the Edhum Community (Eling Handarbeni Hangrungkepi Upaya Madya) a community that regularly held oneday discussion every month in Javanese calendar. This discussion talks about Javanese culture while singing macapat (singing Javanese poetry).

The second technique of data collection is, the interview conducted with drg. J. Sutjahjo Gani (54 years old) - one of Tan Khoen Swie's great-grandchildren living in Jalan Dhoho / Toko Soerabaia (formerly publisher of TKS). In addition to the family, researchers also interviewed members of the Edhum community, namely Mr. Agus (44 years), Joko Pitono (53 years old) and Harardi Agan (57 years old, lecturer). To strengthen the results of the study, the researchers also conducted an interview with Oei Him Hwie manager of Medayu Agung library Surabaya. Oei Him Wie is one of the important informants in this research because of the opportunity to conduct a live interview with Tan Khoen Swie. We had the opportunity to use ego document techniques to construct historical pieces from people who are considered to be related. The ego document allows us to work by combining the archives and daily experiences of the people we interviewed (Oostindie 2016:25-26). The third technique is documentation which includes tracing information from the research results in 
the library as well as personal documents from the Tan Khoen Swie Family. Researchers also added information/data taken from newspapers, magazines that contain information about TKS. Research using genealogical-archaeological method, the existence of archives is a form of information/data that is important to describe the formation of the discourse of the history of the press and public space of Javanese in the colonial period. The archive method is useful for establishing a set of rules that describe the limitations of forms (i) expressibility, (ii) conversation, (iii) memory, (iv) reactivation, and (v) appropriation (Smart 2002:40).

\section{Result and Discussion}

The beginning step to describe the results and discussion of research conducted by first performing depiction of Tan Khoen Swie as a character. Figuration as a character facilitates the explanation of the genealogy traces of Tan Khoen Swie's ideas in publishing business in Kediri. Finding Tan Khoen Swie in a complete picture in the form of a biography of a character is a difficult task to be manifested. The only way to discover is by getting a picture of the fragment of the story which is not intact from the people who are considered to know and recognize, whether they are family, friends as well as former researchers who researched first. We have interviewed these people and made a figuration of figures. The description of Tan Khoen Swie could be still biased and could only be described through a series of constructivism based on collective memory. However, because of the vagueness of the overview of the TKS, the discourse on Tan Khoen Swie continues to exist. This configuration is important to explain the role and contribution of Tan Khoen Swie and his publishing business within the framework of the press movement in East Java. The main analysis of this study lies in the discussion of Tan Khoen Swie's contribution both as an individual and a publisher in developing the Javanese public space in the 1915-1950 colonial period.

\section{Figuration of Tan Khoen Swie (陳坤瑞): Author, mystic and publisher}

Dismantling who is Tan Khoen Swie and his activities in the press movement meansthat we have to talk from three corners. First, this figure should be discussed on the basis of the social history narrative of his life when in Wonogiri and Solo. Second, the figuration have to be done by putting special attention in his friendship with Ki Padmosusastro, a Javanese literary figure in the Sultanate of Surakarta. Lastly, pay attention to the development of his publishing business. The information about who Tan Khoen Swie is and how his work is still vague and difficult to ascertain the truth. The information found in books, writings or researches at the University about its existence is still limited as well as by looking for his writings he wrote himself. The research results conducted by researchers to various places such as Radya Pustaka Museum, national archive documentation and several libraries such as Medayu Agung Library and Panjebar Semangat Collection in Surabaya and family collection on Jalan Doho Kediri showed no encouraging and satisfying results. The results of Tan Khoen Swie's research can only be found in the bibliography, trailers of clippings and books shown through one or two lines of sentences. Information gained more about the printed book from his publishing busines.

The name Tan Khoen Swie first appeared through the book by Boen (1935) "Orang-orang Tionghoa jang Terkemoeka di Java: Who's Who “ from publisher of The Biographical Publishing Center in Solo Central Java. The 237-page book is a neat book of encyclopedias about influential figures of Chinese people, especially those who are rich and having a special closeness with the existence of a temple. Not only covering about the Chinese personality, education and success (wealth) are two important instruments that become the basic requirements of the names that included in the book. This book is interesting to be observed because it displays 1000 faces of Chinese figures who are considered prominent at the time. Selecting Tan Khoen Swie as one of the leading figures of Tionghoa can not be separated from his success to build his publishing business. The publishing business, named after his own name, made Tan Khoen Swie one of the richest person in Kediri economically. We find out that Tan is a generous person. The board of Tri Dharma Triharma Tjoe Hwie Kiong admitted that one of the biggest contributors to the construction of the temple is Tan Khoen Swie. No other information can be developed from the information written in the book about Tan Khoen Swie. 
Tan Khoen Swie (陳坤瑞, in Pinyin language: Chén Kūnruì and often pronounced as Gun Tan Swi), was born around 1883 or 1884 in Wonogiri, a village called Goenoeng Legong in the Doren Siwo region. The possibility of this place now is Mount Sewu-Duren located in Wuryantoro area, Wonogiri regency. The origins of the Tan Khoen Swie family in Wonogiri are quite mysterious, some say that their parents are from poor families who depend on collecting firewood around Legong Mountain in the Wuryantoro area. Formal education was not a priority for Tan's family at the time, in addition to his poverty and due to Dutch colonialism which strongly organize who can have the right to the access of formal Dutch education. Tan spent his childhood and adolescence in a strong Javanese cultural culture. His interest to learn about Java (culture), it is proved by being taught by Mas Ngabei Mangoenwidjojo, one of the Javanese literary and cultural experts from Kediri, East Java.

In his historical record Tan Khoen Swie has no formal education either in Wonogiri or his migrate city in Solo. The history about his family's concern for education is also very difficult to trace. Several books that discuss about his existence also never thoroughly peeled his educational history. Except of Wonogiri, Solo is another place that became an important position in the early days of his life. Solo at that time was the center of the Islamic empire of Kasunanan Surakarta as well as the center of Javanese politics and culture. Tan strongly believes that his life will change if he migrates to Solo rather than living in Wonogiri. His introduction to the world of education came about by chance. While working as a raft driver in the swift currents of the Bengawan Solo River, young Swie often takes people to the hermitage where the royal families are studying. In between dropping off people across, Tan Khoen Swie did not deliberately hear about the Javanese culture lesson that was only allowed in Solo Palace. From the top of the raft, Tan Khoen Swie followed each lecture given by the teacher. Only by hearing Tan Khoen Swie is able to grasp the core of the teachings given by the teacher. Whereas before, Tan Khoen Swie never get any formal education in school. The silent learning effort was finally discovered when the teacher wisely invited Tan Khoen Swie to follow the learning process.

The subjects taught include literature, life guidance and Javanese cultural order (Hartatiningtyas 2010). The existence of Surakarta Sultanate education model was highly respected by colonial government at that time. In this context, Islam and Javanese culture are two things that go hand in hand as the life guides of the Javanese. This is basically an interesting phenomenon that (probably) for the first time, Chinese children can learn about Javanese culture through the circle of the palace. Tan Khoen Swie's contact with this kind of palace learning model will become an important thing for him to grow his fond of for this Javanese culture. Different opinions about the educational background information of Tan Khoen Swie are expressed by Indonesian historians living in Singapore, Suryadinata through his writings "Prominent Indonesian Chinese: Biographical Sketches (4th Edition)". Tan Khoen Swie at the time lived in Solo once one of a student of Mas Ngabei Mangoenwidjojo, a poet who allegedly came from Kediri (Suryadinata 2015:298). If this information is true then Tan Khoen Swie can be said to be educated and has obtained a Javanese education through a teacher.

During his stay in Solo, Tan Khoen Swie became acquainted with Ki Padmosusastro, a writer who later became his mentor and also known as the Father of Modern Javanese Literature. Ki Padmosusastro is an important figure who brings self-esteem to Tan Khoen Swie. Through the figure of Ki Padmosusastro the relation between Keraton Solo and Tan Khoen Swie happened. Ki Padmosusastro is a central figure in Javanese culture, he is a direct disciple of Ronggowarsito. Tan Khoen Swie knew Ki Padmosusastro while still in Solo. He was then able to be friendly friends with Padmosusastro (1843-1926), poet of the palace who is also the Head of Library Radya Pustaka. From here it seems he got access to get books in the palace and then took the initiative to translate it to be read by others. Padmosusastro itself seems to be part of the publishing editorial board of Tan Khoen Swie.

Ki Padmosusastro can be regarded as one who intrigues Tan Khoen Swie towards literature. His friendship did not stop even though Tan then moved to Kediri. But it is getting closer in Kediri. At his home, Tan provides lodging for Ki Padmo to stay when visiting Kediri. Can be in a matter of days 
and sometimes even months. All the necessities of eating and so on are provided by Tan Khoen Swie. Ki Padmosusastro's main task is to create a paper and then Tan who publishes and simultaneously disseminates his writing.

The friendship between Tan Khoen Swie and Ki Padmosusastro, can be seen in the books produced by Ki Padmosusastro. Most of the books are printed through this TKS Publisher. The friendship also indicated that some writers from Yogya, Bojonegoro, Surabaya and Lumajang at Ki Padmosusastro's invitation had stayed for more than three weeks at Tan Khoen Swie's house. None other than this is the efforts of Ki Padmo and Tan Khoen Swie to find good quality texts for publication. From this friendship, Tan Khoen Swie has the right to republish Kalatida, Pustakaraja Fiber and Paramayoga Serat by Raden Ngabehi (RNg) Ronggowarsito. Not only that, Serat Wedhatama by Mangkunegara is also published by Tan Khoen Swie for the services of Ki Padmosusastro. The remains are visible in the building at Tan Khoen Swie's house that has many rooms. This house is also important to be remembered because it has a direct connection to the back of the house, which merges into Gunung Sari grave. In that area there is one place that serves as a meditation room for TKS and his friends including Ki Padmosusastro. It is not surprising that Tan Khoen Swie is a person who loves things that are mystical based on the traces.

This senior journalist and research informant, Oei Hiem Hwie, who met in Surabaya recalled how he met with Tan Khoen Swie at the first time in Kediri. Although vaguely, Om Wie remembers his meeting in 1950 was very memorable. Swie acknowledged to be a very authoritative person and really shows a different class of Chinese people.

He (Tan Khoen Swie) was a very authoritative person. If you see him... Can't resist. His eyes was so strong. As if there is something. So we make it down. I feel this person, a gifted person, sacred. His soul is very strong. But he also very nice person. I still recall he likes to be interviewed in person, to the point, if you want to ask something, he will answer straight away not like the other crossbreed (Interview at 5 September 2016).

The description of Tan Khoen Swie is similarly described by Suryadinata, "He was well-known as a philosopher and a mystic. Wearing long hair and sporting mostache, he looked like a present-day hippie" (2015:289). This information is not unusual, some other informants such as Mr. Agus tomb keeper Mbah Poncolegowo (Tomb of Eyang Gunung Sari) behind Tan Khoen Swie's house got information from his grandfather about this news. According to Agus, who studied the teachings of Confucianism, the supernatural ability of Tan Khoen Swie was obtained when he studied with the mysticism expert from Tulungagung named Tan Tiek Sioe San (Ramamoerti).

The friendship between TKS and Ki Padmosusastro also made TKS interested to have a book printing. It started when TKS was directly involved in daily Bromartani, the newspaper led by Ki Padmosusastro in Solo. Bromartani is believed by Ahmat Adam as the author of the book The Preliminary History of the Press and Awakening of Indonesian Awareness is the first Javanese language newspaper in the Dutch East Indies. Ki Padmosusastro is one of the most important people in this daily and in this place Tan Khoen Swie once lead this newspaper. His experience as head of Bromartani newspaper as well as his life in the field of printing seems to inspire his spirit to open a printing business in Kediri. His effort to build a printing business wasn't so smooth in the beginning. In the early years of establishing the printing business, the Dutch East Indies press policy was very strict. The press was tightly watched under the Dutch East Indies government at that time. Most of the press has a tendency to affiliate with certain races, such as Europe. Java and China (Maters 2003).

From the photos taken around 1930s, it can be seen that the building was a bookstore whose the owner is also the owner of the auto parts store. Signed with capital letters "Tan Khoen Swie Shop, Sedia Boekoe Djawa Melajoe and Ollanda". From that store, can be found well-known books of Java's poets, such as Ronggowarsito's Kalatida, Wulangreh Book of Sri Susuhunan PakubuwonoIV, or Wedatama by Mangkunagoro IV. Also another book by R. Ngabehi Yosodipuro, a poet Padmosusastro, Suwandi Tjitrowasito, and so forth. Arguably the great name of the poets would 
not have appeared without the bookstore's role. Around the 1920s the books were sold for a price of $0.35-0.95$ guilders. At first the publisher was spreading old Javanese-speaking books. But, since the 1950s, they published Latin-literary books. This clearly shows that Tan Khoen Swie has a strong business sense in developing his business.

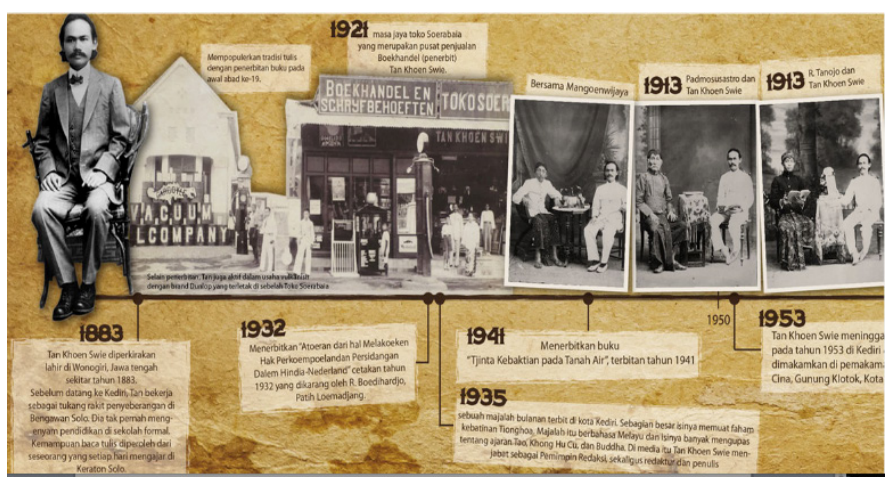

Figure 1.

Development Matrics of Tan Khoen Swie and Boekhandel TKS Source: kediripedia.com 2016

Before his die, Tan Khoes Swie made a will for his families. The first letter was made in front of Notary Raden Soedarmadji Soeriokoesoemo on July 25, 1952 in Madiun. This second letter was finally canceled with a cancellation letter on March 17, 1953. The contents of the will is that the publishing business was handed over to his son, Michael Tanzil. Michael Tanzil is the last traceable descendant of TKS and still actively engaged in his father's printing press. The provisions of the wills made at the notary, then 60 percent of the books that have been printed the ownership as well as the rights belong to Michael Tanzil and which have not been printed into the full rights of Michael Tanzil. The management of TKS publishing was taken over by Michael formally after Tan Khoen Swie died in 1953. Over the next 10 years, the publication of Boekhandel TKS undertook the republishing of sold out books and also collaborated with other publishers.

Michael Tanzil never really lived in Kediri. During his life around 1962, for the purpose of managing the business of publishing TKS he traveled Jakarta-Kediri back and forth. Officially, in 1962 this bookstore and publishing business TKS was closed. All the books are stored into the warehouse and some of the printing machines can not be re-operated. While Michael Tanzil started working at United Press America in 1971. Michael is one of the reliable photographers at United Press. His expertise led him to work at Stringer NBC News in Jakarta. And in 1980, he had served as Deputy Chief Editor of Warta Ekonomi Maritim Reviews Magazine. A documentary movie about Arun's LNG development in Aceh and offshore oil drilling by Total Indonesie in Balikpapan East Kalimantan, also one of his work in 1975-1976. Before he died on March 14, 1993, paralyzed after suffering a stroke for nine years, Michael had written a will on a piece of paper, which read:

Will

I am Michael Tanzil. In the conscious state write this will. Due to my healt is declining. I submit home, painting, and publisher right and all the books to my wife, Yuriah Tanzil so that my child will get along.

24-12-90, Christmas Day

So, it can be said that after the death of Michael Tanzil, Tan Khoen Swie Publishing business as a business was closed. However, the remnants of the legacy of the formation of discourse space and public space is still traceable to the present day. 


\section{Tan Khoen Swie and the development of East Java colonial press}

From 1915-1950, the period study of this research, the configuration of Tan Khoen Swie begins to be depicted gradually toward wider relationships. Disassembling Tan Khoen Swie's relationship with modern Javanese literary character Ki Padmosusastro is one form of the expansion. Second relation of the two figures revealed the access obtained by Tan Khoen Swie into the Surakarta palace collection for the effort of Ki Padmosusastro. Because of that relationship, TKS seems to get the privilege to print the books belong to Surakarta palace so that these books can be enjoyed by many people. Tan Khoen Swie idea to publish ancient javanese texts into Latin letters shows the trust of the palace toward him. This effort is quite astonishing, because translating Javanese script or ancient Javanese script into Latin script has its own difficulties. His translation is actually the core point in the discussion of this research, because the efforts made by Tan Khoen Swie and publishing business play a role in the future in the creation of Javanese public space. Before that, firstly we have to see how the revival of this Chinese press in the 19th century.

At the end of the 19th century the Malay-Chinese Press handled by the Chinese Crossbreed experienced growth (Maters 2003: 43). The rise of the Chinese press in the twentieth century due to the growing sense of nationalism from the pure Chinese (Native Chinese) group and the Chinese economy were at the peak of success. Although the Chinese group were a small minority about $1 \%$ of the population by the end of the nineteenth century, their existence could not be underestimated. Their identity can be seen from Chinese clothing complete with pigtails they must wear until 1911 at the instructions of the Governor (Maters 2003). Since ancient times the crossbreed group compared with the natives or singkeh group, which is the largest group of ethnic Chinese. From among these crossbreed emerge journalists who fought for the interests of their own group. For them, the press is the right medium for spreading new ideas and encouraging the awareness process.

The emergence of national consciousness and the struggle for independence inspired Chinese people to publish newspapers. This is considered as their attempt to spread ideas. In fact, with a higher educational background, they are able to play their voice in politics and journalism sector. Nationalism among the Chinese was a reaction to the actions of the Government of the Indies to control them as a group, but also as a result of Chinese ideas (Suryadinata 1971:7). One of the injustice of the Dutch Indies Government to the Chinese in 1863-1866 was the limitation of their political and economic sectors. Through this restriction scheme, Chinese people may only live in certain kampongs within the city.

Around 1900s this growing national consciousness got a new impetus. The impetus in this case is the unification of Chinese people, who acquired Western education in Batavia, and in establishing a national association called Tjong Hoa Hwe Koan (THHK). The purpose this association was to improve the position of the Chinese in the Dutch East Indies. THHK established a modern schools and published their own organ called, Li Po. As for unofficial organ press, Malay name had been chosen called Warna Warta in Semarang and Chabar Perniagaan which finally renamed as Siang $P o$ in 1930. This newspaper is a speaker for the crossbreed group who were trying to participate in colonial society as well as its institution. In the end, in 1930s this Chinese group began to shift their spirit into a struggle that focus on Indonesia's national movement, to conceived Indonesia as a country.

Through the elaboration of the Chinese-Malay press above, it can be said that the establishment of Tan Khoen Swie publishing business or called Boekhandel Tan Khoen Swie became a milestone of literacy movement for the society in the colonial period. TKS became a well-known publisher with an enormous number of readers, with a total of 400 titles of books more than that published by the government publisher - Balai Pustaka. The history of publishing in Indonesia has a strong relation with TKS. Despite being established by a minority in Indonesia - at that time the indigenous peoples were being colonized so that so many of them were unable to read and write - TKS succeeded in making the Javanese which were part of the indigenous people into a well-known scholar and prominent intellectual. TKS was supported by a group of well off Chinese who has an idelism in 
improving people dignity. Although it was not as big and famous as Balai Pustaka, it is undeniable that the elderly people now still recognize or remember TKS. Boekhandel TKS was a large and famous publisher, despite it being operated in a small town Kediri East Java back in the day.

Tan Khoen Swie in this study is the main character who plays a double role as a publisher and individual (actor). As a publishing business (boekhandel), Tan Khoen Swie acts as a medium or space where the discourse gets its locus. Tan Khoen Swie as an individual focused on the ideas, efforts and actions taken in shaping discourse. In principle, Tan Khoen Swie has transformed classical speech culture into a popular reading culture in the colonial period. This changing culture has been started by TKS since his very first print when TKS publication began to circulate in 1913, two years before the official Boekhandel TKS business was established in Kediri in 1920. The books published by TKS have influenced the configuration of Javanese values (Kejawen) in Javanese society culture. The printed books have diverse themes, ranging from the guidance of Javanese behavior, cookbooks, sexuality and coitus techniques, history, song, agriculture, primbon, Javanese classical literature, as well as Taoist books. Through these themes, TKS introduces the values that exist in every writing, especially about Javanese culture. The diversity of this theme suggests that Tan Khoen Swie wants to target all level of society in spreading his ideas as well as business orientation which was also one of the factors worth considering.

The management of TKS is operated professionally so that in just a few years the name TKS has been widely known among intellectual and scholar. It is inevitably that the name of TKS is always identified with the good quality books published. TKS publishers established around 1915, a few years before Balai Pustaka (a major publication in Jakarta pioneered by the Dutch government) established. In the beginning to broaden the scale of thecompany, TKS was assisted by Chinese writers such as Tjoa Boe Sing, Tan Tik Sioe, Sioe Lian, Tjoa Hien Tjioe and Tan Soe Djwan. No doubt again, when it became TKS prestigious and reputable publishers. To find the manuscript, TKS did not hesitate to invite writers from various regions to work with him. For the writers themselves, it is such an honour and pride to join the TKS. In fact many writers deliberately come from Cilacap, Solo, Ngawi, and other cities just to negotiate with TKS. The famous Javanese poets such as R.Ng Ronggowarsito, Yosodipuro, and Ki Padmosusastro, were boosted by the name of TKS. Without TKS the possibility of their works being known by the wider community is unlikely. Beside the original work, TKS also publish many translations from Dutch or English.

The presence of TKS publishing certainly contributes to the birth of the literacy era - replacing the tradition of speech that was previously only known in the form of tedhakan (hand-written derivative). Javanese songwriter Anjar Any (now deceased), once acknowledged that the publisher of TKS was so productive that it played a role in educating the nation in his day. It is alculated-TKS has published around 400 titles of books. An enormous amount of scale in that period. The books of TKS can be categorized into three types based on the letters and languages used, ie lettered and Javanese, Latincoded in Javanese, and Latin-speaking in Malay. Many of these books are classified as best-sellers of their day, so it is not surprising that some titles should be reprinted to meet readers' requests. Several types of recorded books published up to the end of 1953 recorded 48 books in Malay written in Latin letters, 14 books in Java and 14 Latin letters and Java Javanese language as much as 81 pieces (Kristyowadi \& Moordiati 2012:102).

Most of TKS's books are popular knowledge, such as about oriental, mysticism, prophecy, heroscope, legend and philosophy. For instance the Horoscoop book, the Book of Rama Krishna, Mind Power (Kekoeatan Pikiran), Divination and Science of Human Hunch book, Prophecy expert book (Achli Noedjoem), and Interpretation of dream and its meaning (Ngimpi dan Artinja), such books were the most popular among Indonesians at that time. The books were published around of 1919 to 1956. Through these titles, TKS strives to introduce Javanese values to a wider audience. The diversity of the theme also shows that TKS is trying to develop the target audience and the equally important factor is the effort to expand the scope of the publishing business itself. This situation can be happened because the writers appointed by TKS generally are great poets who are already known by the public. For instance, Serat Kalathida was one of the great success stories of TKS. Serat was very popular 
by the community at that time. Several other works by Boekhandel Tan Khoen Swie such as Djangka Djajabaja, Wulangreh Djarwa, Wedhatama Winardi, Serat Dewarutji, Gatolotjo, and Bhagawat Gita were very familiar works for Javanese society.

A general question arises, who actually read the works of TKS in those days? It is sufficiently stated here that in the colonial period only educated people had the ability to buy books (Anderson 1990). This information also applies to the printing period of Boekhandel Tan Khoen Swie in Kediri. Only economically literate and economically well off people can obtain books in those days. The elite who had been "enlightened" at the time, although in small numbers, were the ones who supported Tan Khoen Swie's publishing business. This assertion was conveyed by the pengayat group leader in Kediri, Mr. Joko Pitono, who became a collector and member of the Edhum community / a reviewer of books published by TKS. However, the culture of reading was gradually began to spread among the lower society. Apart from the authors who have big names, the use of language and writing styles is another factor that impacts the widespread of books published by TKS. The languages used by TKS are considered as alternative languages, structured and easily accepted by the Javanese society.

Culture and religion were the theme that most widely printed compare to the others. As we see that the publisher of TKS has actually printed another books in a huge amount. In the former printing, we can still find manuscripts that are ready to publish in thousands pieces. Culture and religion were the most popular book that most widely printed by TKS. TKS actually has been printed more than books in various theme as well. In the former printing, can still be found manuscripts that are ready to rise and the number reaches thousands. Some manuscripts such as Serat Kalathida and Djangka Djajabaja were the last horoscope books (primbon) published in 1953 (the fifth edition). Another books such as Darmagandul and Gatolotjo were also enjoyed very much at that time especially among Javanese Abangan groups, those who settled in rural areas.

Among the thousands of books and writings that were produced by TKS publishers, those three writings seem to have a space of debate in the community. For instance, the publication of Gatolotjo and Darmagandul in 1955 is still read clandestinely until present time. Both books of fiction that tells of the entry of Islam to Java and the collapse of the Majapahit Kingdom also creates a picture not far from the male sex. Tan Khoen Swie Publisher, has published it as a second edition. In addition, in the 1920s, Darmogandul had protested the Islamic community and China when first published in an almanac. Darmogandul, that was written in Javanese and in the form of sekar or Javanese poetry, indeed scorns the Chinese, the Arabs, and attacks Islam. Darmogandul was once a reference of believers. The books, published by Tan Khoen Swie in the 1920s, has generated mixed reactions from the Javanese community at that time. Although regarded as a poem or sekar but its existence is quite prominent at that time. In his book on integrated history studies, Lombard (2005:152) specifically mentions the role of Boekhandel TKS in the transformation of Javanese literature at the time. Its publication is awaited to Surakarta in the west and east to Banyuwangi.

The books published by Boekhandel TKS, based on our observations during the research were still getting attention from Javanese people especially those living in Kediri, the Edhum community. This community is regularly held a gathering on Monday night Legi, to discuss works by Tan Khoen Swie. Located on the 3rd floor of Surabaya Store, the former building of the Khoen Swie relics, they regularly gather to study the meanings in every work of Tan Khoen Swie. Members of this activity consists of various professions such as doctors, civil servants, private employees, laborers, lecturers, teachers as well as pedicab drivers. They sit together to discuss a book or several books in a single meeting. In fact, not infrequently for one book they can discuss for approximately ten meetings. Joko Pitono and Agus, both were our research informants, say almost always take the time to attend the meeting that held in every 35 days. For them, the relics of Tan Khoen Swie must be preserved because the history of the bookkeeping in colonial Indonesia was conceived here.

\section{Javanese public space in colonial period: The beginning discourse}

In the colonial era, movements against colonial rule began to grow especially after the enactment of 
ethical politics (etische politiek) by the colonial government in 1900-1930. It is inevitable that the implementation of ethical politics has spawned a group of intellectual Javanese society (Frederick 1989:43, Suwirta 1999:84). This colonial-educated group was regarded as a smart person by the people, so at that time these educated people occupied the top position in the strata of modern Javanese society even though this group remained under the social strata of the Dutch people. This period is called the period of modernization in the Javanese society, started with the development of trade, infrastructure development, communication and transportation facilities and the increasingly heterogeneous social coatings in urban areas that form a consumer society requiring rapid communication media (Riyanto 2000, Wertheim 1956). These well educated societies began to use the media of communication through newspapers and stenselan to create the awareness of society and nation. It is important to note that the printed communication model has altered interpersonal oral communication patterns to impersonal communication patterns (Adam 2003, McLuhan 1994).

Using his own name as his business name, Tan Khoen Swie set up a publishing business with the ultimate goal of reprinting old Javanese manuscripts to be read by all level of societies. The works can be categorized into the writings of education, history, cuisine (culinary), religion, culture field and the mostly were about literature (Kristyowadi \& Moordiati 2012). It is important to note that Tan Khoen Swie (TKS) function of business publishing is not only seen in the economic aspect, but also in its role in preserving Javanese culture. Publishing businesses in big cities such as Batavia (Jakarta), Bandoeng (Bandung), Vorstenlanden (Surakarta and Yogyakarta), Semarang, Soerabaja (Surabaya) and Malang, began to thrive due to the large number of investments in this business (Adam 2003, Riyanto 2000). With the percentage ownership of publishing business dominated by white people (the Netherlands), Chinese (Chinese) and a little indigenous in the future. Initially, this publishing effort was marked by the emergence of leaflets printed by students for the purpose of propaganda of colonial occupation and the situation began to shift as press efforts led to trade and business.

The existence of Boekhandel Tan Khoen Swie was at the same time as the strengthening of the press movement in several cities in the Indies at that time. Through the leading daily Sinar Hinda the characteristics of the movement or "press revolution" takes place. The press revolution in Java became an influential main weapon (Subijanto 2017:1357). However, different characters appear in Tan Khoen Swie's press movement. Press movements are not as common as those found in newspapers. The issue of TKS moves in the realm of culture and creates an intellectual movement for the Javanese. There is an advantage to Tan Khoen Swie's move in the awareness of Javanese society at that time through the publication of the book. If at that time he chose to publish newspapers as with other publishers then there is the possibility of collision with the Dutch becomes very open (Maters 2003). From the very beginning, Tan Khoen Swie has built the image as a cosmopolite and this makes his figure acceptable among Dutch, Chinese and Javanese. The figure of Tan Khoen Swie also affected the acceptance of the literatures widely. The literatures oriented on Javanese culture were of course escaped Dutch suspicion so that its development encouraged the creation of a Javanese public space. The existence of public space in Javanese society is not so clear as it is found in the western literature. The Javanese worldview that does not separate its self-consciousness from reality results in the consequence that the concept of Javanese power is one of the extensions of reality.

The history of public space on Javanese is not known in literary works or textbooks on Javanese culture. Public spaces are not known as Habermas provides definitions through his writings. A bold argument given by Subijanto (2014) which states that the General Meeting is a form of public space that existed in the colonial period. We agree with the opinion submitted by Subijanto. The General Meeting is indeed a form of colonial public space but there is a tendency that such a public space does not give the impression of a dialogical process within it. However, we see, that to get to the mass situation in the General Assembly the process of consciousness should take shape first. Here we capture the role of the press and the publishing/print media plays its primary role. Tan Khoen Swie has been preparing for this Javanese public space for quite long period of time, especially in understanding their culture. 
In particular, the print culture has given us the opportunity to construct the Javanese public space on aspects of the Javanese political struggle. In some cases it lies in the presence of newspapers in the political struggle to raise the awareness of nationalism (Anderson 2006, Dhakidae 2001, Anderson 1990). The presence of Boekhandel Tan Khoen Swie is a picture of the forms of the struggle of a Chinese ethnic who loves Javanese culture in order to be parallel to European groups. The description of TKS also reflects a form of political struggle over oppressed groups through literacy efforts. In addition, the idea of public space emerges in the TKS works in establishing a dialogue room among the Javanese in a broader sense. Through the works published by TKS, the consciousness of the Javanese as entity unity is formed. The issue of TKS is more focused on creating a dialogue room through books and not on newspapers. Through these books, the voices of the Javanese community are voiced and then taken to meetings among the citizens. This space then forms a polemic and discourse on controversial social issues in society.

Our investigations show that the presence of a public space based on polemics and dialogue is recognized as bringing courage to the Javanese community in the fight against culture. The dialogue sphere grew into "power sites, coordinating joint activities through speech and action", such as the values and norms of the entry of Islam into Java. The efforts made by Tan Khoen Swie Unknowingly have led to a period of enlightenment for these Javanese. The idea of Tan Khoen Swie has encouraged the expression of the ability of individual Javanese individuals to judge something independently. Knowledge and information exchange takes place so quickly between individuals whether it takes place in homes, roads, markets and even formal meetings. The French historian Lombard (2005) and the English historian Ricklefs (2007) acknowledge Tan Khoen Swie's contribution to that enlightenment period.

Polemic spaces and discourses can occur through the publication of TKS as previously selected. Incoming book texts have been analyzed sharply by Tan Khoen Swie. Most likely the controversy and economic considerations are the terms of analysis performed by Tan Khoen Swie. We suspect that a strong business spirit also plays a role in Tan Khoen Swie to determine what books or writings the market will accept. We see that there was an investigation conducted by Tan Khoen Swie in the process of determining the market. Of course the marketing process through advertisements in newspapers and Panjebar Semangat magazines also plays an important role. In fact, almost every book published by TKS on culture and religion provided a stimulus for the formation of public opinion in the colonial period. The publication of Serat Darmogandul and Gatolotjo, for instance, were two publications that have shaped the opinion of the entry of Islam into the land of Java. In fact, that discourse still remains to be the case until now. On several occasions, it seems as though the believer's group has made these two books as a kind of "grip" about their religion. These things happened because of the appropriateness of the view between the author of the book and the reader. At that time, the life of the Abangan groups in Kediri still dominates so that these readings easily arouse public opinion. Although the formation of public opinion space was not held radically all at once.

In addition, Tan Khoen Swie was able to reflect the will and actions of the community in their community. Tan Khoen Swie can frame the situation in the society and then make improvements through its publications. It should be admitted that the books published by TKS create a critical expression and protest against the circumstances of the colonial period. Not only about the establishment in culture and religion, but also the oppression by the elites. The fact that the use of books to form the formation of public opinion space, allows a controversial discourse to surface. For instance, Tan Khoen Swie sent each book to be reviewed by Tjahaja Timoer. For example, Kawedar Kidungan book published in 1941 as thick as 98 pages published by Tjahaja Timoer daily on November 14, 1941. It is very important that the existence of the review on newspaper, the distribution will be economically viable and public discourse will be maintained. For Tan, this exciting attempt was made to preserve the Javanese cultural discourse which he always held in every manuscript he received.

To be able to have a book publishing is a visionary action by TKS as proposed by Anderson (2006) and Yamamoto (2011) who saw that alongside trains, the print media industry has played an important 
role in growing the awareness of nationalism. In this context, the emergence of public criticism create what is called nationalist consciousness. Indeed, the issue of nationalism was still a new discourse in the 1920s. This coincides with the establishment of TKS as a publisher in East Java. But, it is important to bear in mind that nationalism is not an important concern of the TKS publishers at that time. Tan Khoen Swie as the person who holds the decision in the printing industry is more concerned with the spirituality and mysticism of Javanese culture. For this reason, Boekhandel Tan Khoen Swie was not classified by the Dutch East Indies government as a potentially problematic issuer.

Apart from the visionary actions undertaken by TKS by opening Boekhandel, TKS has been able to trigger the emergence of public space for the Javanese. The role of TKS in the establishment of Javanese public spaces can be seen as follows: (1) Through the publication of TKS, the Javanese community has a place to interact, conduct various activities together and share, including social, economic and cultural interactions, with the main emphasis on social activities. It means that the publications of TKS open a space for Javanese communities and people whose concerned with the Javanese community to create dialogue spaces, (2) Through these TKS publications, it created space for the society to share space and time. For example,the place can be in a meeting room or in a market. Everyone has the same resources and opportunities to communicate at that time. There is some sort of "communication" space formed between communities, 3) So that the changing from the speech culture to the literacy culture also affect the way of communicating the Javanese (Anderson 1990).

Tan Khoen Swie's published works review and research activities still remains and exist and this community is part of the existing discourse. The discourses that perhaps the most interesting and up to date untill now are the debates on tradition and modernity. In some of its publications, TKS often publish a controversial publications or issues, but if we observed carefully, the both issues were about the question of tradition and modernity that leads to Javanese values and norms. Almost in every his publication associates the question of morality as a Javanese to the public.

\section{Conclusion}

During the reign of the Dutch East Indies there were control toward publishing institutions throughout Java and Sumatra, Boekhandel Tan Khoen Swie based in Kediri East Java was present as an alternative printing press in the movement. His decision to concentrate only on publishing books about Javanese culture was the right decision at that time. The choice of publishing books made the Netherlands Indies government unaware of supervising this publishing business activity. Such choice made Boekhandel TKS can freely disseminate the principles of Javanese cultural teachings in society. The Dutch East Indies government did not realize that the efforts undertaken by the publisher of TKS is the steps of the modernity of the Javanese that at that time. The development of this printing using three stages that are the use of Javanese language with Javanese script, Javanese language with Latin script, Malay language with Latin script in its publications. This is one of the transformation from a speaking culture into reading culture as well as writing culture in Jvanese Culture.

The transformation process, strongly influenced by Tan Khoen Swie as a critical individual towards of Dutch colonialism. This is shown through his cosmopolitan attitude. On the other hand, Tan Khoen Swie was really open maintaining relationships with Chinese and Javanese. On his early introductory period with Ki Padmosusatro, Tan Khoen Swie had been introduced about the culture of Javanese culture so that his fond of this culture strongly embeded. This is also become topic of the discussion how spirituality and criticism of morals are the main themes in his writing. The success of Tan Khoen Swie is also due to his ability in management / economics field, mastery of language and spirituality in looking for a decent work to be published. His cosmopolitan is one of the strength that TKS can be accepted at all level of society at that time. His decisions in maintaining and managing his printing was very precise in that era.

The creation of the Javanese public space has been initiated by the TKS with the emergence of dialogues about classical Javanese literature at that time. Through the books that had been published by Boekhandel TKS, Tan Khoen Swie has a great contribution to the creation of alternative discourse 
in the discourse of Javanese culture. The published books are important and perhaps controversial. The formation of the Javanese public space was conceived by the TKS through the dialogues about classical Javanese literature at the time which was written in the important books published by TKS and perhaps also controversial. Tan Khoen Swie has also a great contribution to the creation of alternative discourse in the discourse of Javanese culture. The establishment of public space through three stages: (1) the emergence of polemics, public opinion and discourse, (2) the establishment of critical public attitude toward the colonial government, and (3) the emergence of public space mechanisms in the meeting rooms, markets and other places. Through his publications, the Javanese were accustomed to dialogue in a Javanese public space mechanism. In other words, Tan Khoen Swie brought the form of establishment a balanced public space in the society in that era.

\section{Referrences}

Adam A (2003) Sejarah Awal Pers dan Kebangkitan Kesadaran Keindonesian. Jakarta: Hasta Mitra. Anderson B (1990) Language and Power: Explroring Political Culture in Indonesia. Ithaca: Cornell University Press.

Anderson B (2001) Imagined Commuties: Komunitas-komunitas Terbayang. Jakarta: Insist Press.

Anderson B (2006) Imagined Communities: Reflections on the Origins and Spread of Nationalism. London: Verso.

Baker KM (1996) Defining the Public Sphere in Eighteenth? Century France: Variations on a Theme by Habermas. In: C Calhoun (ed). Habermas and the Public Sphere. 4th edn. Cambridge, Massachusetts \& London: The MIT Press.

Boen TH (1935) Orang-orang Tionghoa jang Terkemoeka di Java: Who's Who. Solo: The Biographical Publishing Centre.

Calhoun C (1996) Introduction: Habermas and the Public Sphere. In: C Calhoun (ed). Habermas and the Public Sphere. 4th edn. Cambridge, Massachusetts \& London: The MIT Press.

Dhakidae D (2001) Memahami Rasa Kebangsaan dan Menyimak Bangsa sebagai Komunitaskomunitas Terbayang. In: B Anderson (ed). Imagined Commuties: Komunitas-komunitas Terbayang. Jakarta: Insist Press.

Eley G (1996) Nations, Publics, and Political Cultures: Placing Habermas in the Nineteenth Century. In: C Calhoun (ed). Habermas and the Public Sphere. 4th edn. Cambridge, Massachusetts \& London: The MIT Press.

Foucault M (1972) The Archeology of Knowledge and the Discourse on Language. Translated by A. M. S. Smith. New York: Pantheon.

Frederick WH (1989) Pandangan dan Gejolak, Masyarakat Surabaya dan Lahirnya Revolusi Indonesia (Surabaya 1926-1946). Jakarta: Gramedia.

Habermas J (1990) Strukturwandel der Öffentlichkeit. Untersuchungen zu einer Kategorie der bürgerlichen Gesselschaft. Frankfurt am Main: Shurkamp.

Hartatiningtyas S (2010) Gelar dan Ageman Pisowan Surakarta Hadiningrat. Surakarta: Intermedia Paramadina.

Kali A (2013) Diskursus Seksualitas Michel Foucault. Maumere: Penerbit Ledalero.

Kartodirjo S (1992) Sejarah Pergerakan Nasional. Jakarta: Gramedia.

Kaviraj S (1997) Filth and the public sphere: Concepts and practices about space in Calcutta. Public Culture, 10 (1):83-113.

Kristyowadi BI \& Moordiati (2012) Boekhandel Tan Khoen Swie 1915-1950an: Nilai kultural dari terbitan TKS. Verleden, 1 (1):99-109.

Lombard D (2005) Nusa Jawa: Silang Budaya. Batas-batas Pembaratan. Jakarta: Gramedia Pustaka Utama, Forum Jakarta-Paris \& École française d'Extrême-Orient.

Maters M (2003) Dari Perintah Halus ke Tindakan Keras. Jakarta: KITLV Jakarta \& Hasta MitraPustaka Utan Kayu.

McLuhan M (1994) Understanding Media: The Extension of Man. London and New York: MIT Press. 
Oostindie G (2016) Serdadu Belanda di Indonesia 1945-1950. Translated by S. Moeimam, N. Santoso, and M. Sutedja-Liem. Jakarta: Yayasan Obor Indonesia.

Ricklefs MC (2007) Polarizing Javanese Society: Islamic and Other Visions (1830-1930). Honolulu: University of Hawai'i Press.

Riyanto B (2000) Iklan Surat Kabar dan Perubahan Masyarakat di Jawa Masa Kolonial (1870-1915). Yogyakarta: Tarawang.

Scheurich JJ \& McKenzie KB (2011) Metodologi Foucault: Arkealogi dan Genealogi. Dalam: Denzin NK \& Lincoln YS (eds), Dariyatno (tran.) The Sage Handbook of Qualitative Research 2. 3rd edn. Yogyakarta: Pustaka Pelajar.

Smart B (2002) Michel Foucault. Key Social. Edited by P. Hamilton. New York: Taylor and Francis Group.

Smith NH (1992) Modernity, Crisis and Critique: An Examination of Rival Philosophical Conceptions in the Work of Jürgen Habermas and Charles Taylor. Thesis, University of Glasgow.

Subijanto R (2014) Ruang publik dulu dan sekarang. LKIP Indoprogress, 16 (5 April):1-8.

Subijanto R (2017) Enlightenment and the revolutionary press in colonial Indonesia. International Journal of Communication, 11:1357-1377.

Suryadinata L (1971) The Pre-World War II Peranakan Chinese of Java: A Preliminary Survey. (Paper International Studies). Southeast Asia Series No. 18.

Suryadinata L (2015) Prominent Indonesian Chinese: Biographical Sketches. Singapore: ISEASYusof Ishak Institute.

Suwirta A (1999) Zaman pergerakan, pers, dan nasionalisme di Indonesia. Mimbar Pendidikan, 4:8393.

Tuchman G(1983) Consciousness Industries and the Production of Culture. Journal of Communication, 33 (3):330-341.

Wertheim W (1956) Indonesian Society in Transitions. Bandoeng: Soemoer Bandoeng.

Yamamoto N (2011) Print Power and Cencorship in Colonial Indonesia, 1914-1942. Thesis, Cornell University. 